\title{
MODEL FORMULASI STRATEGI PENINGKATAN MUTU DAN RELEVANSI PENDIDIKAN TEKNOLOGI DAN KEJURUAN
}

\author{
Suharno, C. Sudibyo, Bambang P., Ernawati S. \\ Pendidikan Teknologi dan Kejuruan FKIP UNS Surakarta \\ myharno@yahoo.com
}

\begin{abstract}
Abstrak. Era modern membuktikan bahwa antara Perguruan Tinggi (PT) dengan perusahaan terdapat banyak kesamaan, antara lain sama-sama memiliki pelanggan, memroses dan menghasilkan produk/jasa, mengelola SDM, keuangan, dan pelanggan. Berdasarkan kesamaan yang ada PT harus memiliki manajemen yang kuat layaknya perusahaan. Diberlakukannya sistem manajemen PT berbasis Strategic Bussiness Unit (SBU), setiap Jurusan, bahkan Program Studi dituntut memiliki perencanaan strategis (renstra). Dalam upaya meningkatkan mutu dan relevansi lulusan, PTK dituntut memiliki renstra yang efektif dan efisien. Berdasarkan penelitian awal diketahui bahwa Tim renstra di beberapa PT mengalami kesulitan dalam menyusun renstra. Hal ini disebabkan oleh banyak faktor, diantaranya adalah kurangnya pemahaman tentang konsep dan metode yang digunakan untuk menyusun renstra. Penelitian ini bertujuan mengembangkan formulasi strategi untuk PTK menggunakan integrasi SWOT kuantitatif dan kualitatif agar diperoleh renstra efektif. Obyek dalam penelitian ini adalah Jurusan Pendidikan Teknologi dan Kejuruan Prodi PTM dan PTB FKIP UNS. Subyek penelitian adalah Tim Peneliti, Tim perumus Renstra, Pimpinan Prodi dan Jurusan, serta stakeholder terkait. Hasilnya menunjukkan bahwa memformulasi strategi merupakan pekerjaan yang membutuhkan perhatian serius. Hal ini mengingat PT memiliki lingkungan internal dan eksternal yang tak terbatas sehingga memerlukan perhatian khusus dalam melakukan analisis lingkungan. Dengan melakukan integrasi analisis SWOT kuantiatif dan kualitatif diperoleh rumusan strategi yang efektif.
\end{abstract}

Kata kunci : Sumber daya PTK, integrasi SWOT, renstra efektif

\begin{abstract}
The modern era proves that between Higher Education with a companies there are many similarities, among others, have the customer, process and products / services, manage the human resources, finance, and customer. Based on the similarity of them, higher education should have a strong management like a company. Enactment of higher education management system based on Strategic Business Unit, each Department, even the study program are required to have a strategic planning. In an effort to improve the quality and relevance of graduates, Technological and Vocational Education (TVE) required to have an effective and efficient strategic planning. Based on preliminary research shows that the team of strategic planning on higher education has experienced some difficulty to formulate the strategic planning. This is caused by many factors, including the lack of understanding of the concepts and methods used to formulate the strategic planning. This research aims to develop a formulation of a strategy for TVE using quantitative and qualitative SWOT integration in order to obtain an effective strategic planning. Objects in this research is the Department of TVE on Sebelas Maret University. Subjects were Research Team, Strategic Planning team, and other relevant stakeholders. The results show that formulating the strategy is a job that requires serious attention. The TVE has an internal and external environment of infinite so that requires special attention in the environmental analysis. With the integration of qualitative and qualitative SWOT so the effective strategy has been successfully formulated.
\end{abstract}

Keywords : TVE Resources, SWOT integration, effective strategic planning

\section{PENDAHULUAN}

Sebagai lembaga penyelenggara pendidikan tinggi yang mengelola berbagai sumber daya, perguruan tinggi setidaknya memiliki 5 dimensi yang melekat, yaitu dimensi keilmuan, pendidikan, sosial, etika, dan korporasi. Dimensi korporasi mengandung makna bahwa PTK harus dipersepsikan dan dikelola sebagaimana layaknya sebuah perusahaan. Tidak dapat dipungkiri bahwa antara perguruan tinggi dengan perusahaan terdapat banyak kesamaan, antara lain sama-sama memiliki pelanggan, memroses dan menghasilkan produk/jasa, serta mengelola sumber daya manusia, keuangan, dan pelanggan. Berdasarkan kesamaan yang ada maka perguruan tinggi harus memiliki manajemen yang kuat layaknya sebuah korporasi. (Eko Indrajit, 2005: 4)

Diberlakukannya sistem manajemen perguruan tinggi berbasis Strategic Bussiness Unit $(S B U)$, setiap jurusan, bahkan program studi dituntut untuk memiliki perencanaan strategis 
(renstra). Dalam upaya meningkatkan mutu dan relevansi lulusan, PTK dituntut untuk memiliki renstra yang efektif dan efisien. Berdasarkan penelitian awal diperoleh informasi bahwa Tim renstra PTK di 3 perguruan tinggi di Indonesia (UNS Surakarta, UST Yogyakarta, dan UNDANA NTT) mengalami kesulitan dalam menyusun renstra yang efektif dan efisien. Hal ini disebabkan oleh banyak faktor, diantaranya adalah kurangnya pemahaman tentang konsep dan metode yang digunakan untuk menyusun renstra. Faktor lain yang terjadi adalah kurangnya dukungan dari pimpinan, serta minimnya anggaran yang disediakan. Penghambat tersebut mengakibatkan rumusan renstra ditentukan dengan metode yang kurang sistematis.

Berdasarkan penelitian awal diketahui bahwa rumusan strategi yang ada belum ditentukan dengan mengunakan analisis SWOT secara benar. Berdasarkan kajian normatif terhadap sisten penjaminan mutu perguruan tinggi seharusnya penentuan strategi didasarkan atas analisis SWOT secara benar. Analisis SWOT dilakukan dengan dua pendekatan yaitu kuantitatif dan kualitatif. Makalah ini menyajikan model perumusan strategi untuk Pendidikan Teknik Mesin dengan mengintegrasikan pendekatan SWOT kuantitatif dan kualitatif..

Dalam Oxford English Dictionary, strategi diartikan sebuah rencana, metode, atau serangkaian siasat (manuver) untuk memperoleh tujuan yang telah ditetapkan. Sedangkan menurut Oster (1999: 2), strategi adalah sebuah komitmen untuk melakukan satu set tindakan lebih baik dari yang lain. Hitt, (2005: 7), mendefinisikan strategi adalah satu set rancangan tindakan yang terkoordinasi dan terintegrasi untuk mengeksploitasi kemampuan yang ada dan mendapatkan keuntungan kompetitif. Abraham (2006: 7) mendeskripsikan Strategy is how a company actually competes. Hal ini mengandung pengertian bahwa strategi menunjukkan bahwa bagaimana sebuah organisasi secara nyata memiliki kemampuan dalam melakukan kegiatannya. Strategi terkait dengan apa yang organisasi lakukan, sebaik apa aktivitas itu dilakukan di dalam sebuah perencanaan. Sedangkan menurut Allio (1990: 8), mendefinisikan bahwa strategy is the art of deploying resources toward market opportunities in a way that distinguishes a bussines from its competitors. Hal ini mengandung pengertian bahwa strategi merupakan sebuah seni penyebaran segala sumber daya untuk memperoleh peluang pasar dengan cara melakukan sesuatu yang berbeda dengan para kompetitor.

Bryson (1988: 19), mengungkapkan strategi dapat diartikan sebagai suatu pola tujuan, kebijakan, program, tindakan, keputusan, atau alokasi sumber daya yang menunjukkan jati diri suatu organisasi, hal-hal yang dilakukannya, dan alasan melakukan hal-hal tersebut. Dengan demikian, strategi merupakan perluasan dari misi untuk menjembatani antara organisasi tersebut dengan lingkungannya. Strategi umumnya dibuat untuk menanggapi isu strategis, yaitu merupakan garis besar tanggapan organisasi tersebut terhadap pilihan kebijakan yang fundamental. Bila pendekatan tujuan umum yang dipakai, maka strategi dirumuskan untuk mencapai tujuan tersebut dan bila pendekatan visi yang dipakai, maka strategi dikembangkan untuk mencapai visi tersebut. Menurut Zohrabi (2011: 205) menyatakan bahwa strategi adalah 
rencana tentang apa yang ingin dicapai atau hendak menjadi apa suatu organisasi di masa depan (arah) dan bagaimana cara mencapai keadaan yang diinginkan tersebut (rute).

Secara histori, kata strategi awalnya berarti siasat, rencana, metode, yang digunakan untuk dunia militer yang lebih spesifik untuk tujuan memenangkan perang. Pada tahap berikutnya strategi diaplikasikan di dunia bisnis yang bertujuan untuk memenangkan persaingan mutu produk dan jasa. Strategis berarti berdasar siasat, metode, atau rencana yang cermat mengenai kegiatan untuk mencapai sasaran khusus. Mengingat kontribusinya yang luar biasa, strategis banyak diterapkan di sektor publik atau nirlaba. Sehingga LPTK yang bergerak di sektor publik dan nirlaba dengan bisnisnya adalah lulusan dan ilmu pengetahuan perlu menerapkan pola strategis untuk mencapai tujuan yang telah ditetapkan

SWOT adalah salah satu alat manajemen yang digunakan untuk melakukan analisis lingkungan dalam proses perancangan perencanaan strategis. SWOT adalah singkatan dari strengths, weakness, opportunities, and treats, yang berarti kekuatan, kelemahan, peluang dan ancaman. Matriks SWOT menganalisis kekuatan dan kelemahan internal serta peluang dan ancaman eksternal untuk mendapatkan strategi masa depan yang menjanjikan (Rauch, 2007). Perlu dicatat juga bahwa SWOT merupakan alat strategis mengakomodasi kekuatan dan kelemahan internal dengan peluang eksternal dan ancaman.

Analisis SWOT adalah analisis sistematis untuk mengidentifikasi faktor-faktor internal maupun eksternal suatu organisasi yang selanjutnya akan digunakan sebagai dasar untuk merancang dan merumuskan strategi dan program kerja. Jadi melalui analogi dari berbagai faktor, bisa menyajikan empat jenis strategi seperti SO, ST, WO dan WT (Abraham, S.C., 2005: 36). Analisis internal meliputi peniaian terhadap faktor kekuatan (Strengths) dan kelemahan (Weakness). Sementara, analisis eksternal mencakup faktor peluang (Opportunities) dan tantangan (Threats). Ada dua macam pendekatan dalam analisis SWOT, yaitu pendekatan kualitatif matrik SWOT dan kuantitatif matrik SWOT (Rangkuti, 1997: 17). Pendekatan kualitatif matriks SWOT sebagaimana dikembangkan oleh Kearns menampilkan delapan kotak, yaitu dua paling atas adalah kotak faktor eksternal (Peluang dan Tantangan) sedangkan dua kotak sebelah kiri adalah faktor internal (Kekuatan dan Kelamahan). Empat kotak lainnya merupakan kotak isu-isu strategis yang timbul sebagai hasil titik pertemua antara faktor-faktor internal dan eksternal.

\section{METODE}

Obyek dalam penelitian ini Pendidikan Teknik Mesin FKIP UNS Surakarta. Target penelitian adalah mendapatkan strategi dengan mengintegrasikan analisis SWOT kuantitatif dan kualitatif. Variable internal dan eksternal yang dianalisis dalam riset ini meliputi 15 komponen (lihat tabel 1). Adapun langkah-langkah yang dilakukan untuk menghasilkan strategi di Prodi PTM FKIP UNS adalah sebagai berikut: 


\section{Langkah 1 . Melakukan riset SWOT Kuantitatif.}

Dengan melakukan riset SWOT kuantitatif, isu-isu strategis dapat diketahui. Dalam melakukan riset SWOT kuantitatif ini menggunakan instrumen berupa kuisioner. Responden ditentukan sejumlah 40 orang meliputi dosen, alumni, dan mahasiswa. Penentuan sampel dengan purposive sampling.

Langkah 2. Mencari posisi kuadran organisasi secara kuantitatif dan kualitatif.

Berdasarkan langkah 1, dapat ditentukan posisi kuadran dari organisasi yang ditinjau baik secara kuantitatif maupun kualitiatif. Dengan cara mengurangkan S dengan W dan O dengan T, dapat diketahui posisi kuadran dari organisasi. Berdasarkan posisi kuadran, dapat diprediksi kea rah mana organisasi akan dikembangkan.

Langkah 3. Mengembangkan strategi.

Berdasarkan isu-isu strategis yang diperoleh dari riset SWOT kuantitatif maka strategi dapat dikembangkan. Metode yang digunakan untuk menyelesaikan langkah ini adalah dengan menggunakan matrik SWOT kualitatif yang berisi 8 kotak. Kotak-kotak tersebut berisi isu strategis dari masing-masing SWOT dan strategi antara SO, ST, WO, dan WT. Dengan menyeimbangkan faktor internal dan eksternal maka strategi dapat dikembangkan.

\section{Langkah 4. Menentukan alternatif strategi}

Langkah ini tim perumus strategi melakukan inventarisasasi berbagai strategi yang mungki diambil guna menjawab isu strategi yang telah diperoleh dari langkah 1. Berbagai strategi yang mungkin diambil ini selanjutnya disebut sebagai alternative strategi, artinya strategi yang ada masih bersifat kumpulan strategi yang masing-masing strategi memilki peluang yang sama untuk dipilih sebagai strategi. Semakin banyak alternatif strategi semakin banyak memberikan ke mudahan bagi tim untuk menentukan salah satu startegi pilihan yang terbaik.

Langkah 5. Strategi pilihan.

Pada langkah 5 ini tim perencana melakukan analisis secara seksama terhadap alternatif strategi yang ada untuk ditentukan strategi terbaik yang betul-betul menjawab isu strategis yang ada. Cara yang efektif untuk menghindari ambigu dan subyektifitas keputusan, maka tim dapat mengacu kepada diagram SWOT kualitatif (posisi kuadran untuk masing-masing variable). Selanjutnya pada langkah ini pula tim dapat melakukan rekapitulasi pilihan strategi yang akan digunakan sebagai saran kepada para penentu kebijakan untuk mengambil keputusan program yang strategis. 


\section{HASIL DAN PEMBAHASAN}

\section{Hasil riset SWOT kuantitatif}

Berdasarkan hasil riset SWOT kuantitatif berikut ditampilkan rekapitulasi nilai dari masingmasing variabel.

Table 1. Rekapitulasi penilaian SWOT prodi PTM

\begin{tabular}{llcccc}
\hline No & \multicolumn{1}{c}{ Variabel } & S & W & O & T \\
\hline 1. & Visi, misi & 0.210 & 0.180 & 0.240 & 0.200 \\
2. & Mahasiswa & 0.262 & 0.240 & 0.296 & 0.296 \\
3. & Kurikulum & 0.278 & 0.240 & 0.296 & 0.192 \\
4. & Dosen & 0.288 & 0.236 & 0.320 & 0.272 \\
5. & Sarana Prasarana & 0.239 & 0.262 & 0.272 & 0.308 \\
6. & Keuangan & 0.231 & 0.259 & 0.252 & 0.126 \\
7. & Proses Pembelajaran & 0.295 & 0.292 & 0.333 & 0.306 \\
8. & Manajemen & 0.196 & 0.244 & 0.336 & 0.332 \\
9. & Peran Dunia Usaha dan Industri & 0.150 & 0.150 & 0.174 & 0.200 \\
10. & Teknologi Informasi dan Komunikasi & 0.150 & 0.150 & 0.139 & 0.100 \\
11. & Unit Produksi & 0.088 & 0.138 & 0.130 & 0.152 \\
12. & Kerjasama & 0.118 & 0.120 & 0.190 & 0.138 \\
13. & Peran Pemerintah & 0.272 & 0.272 & 0.288 & 0.320 \\
14. & teknisi / laboran & 0.101 & 0.132 & 0.120 & 0.160 \\
15. & Penelitian \& Pengabdian & 0.308 & 0.240 & 0.304 & 0.336 \\
\hline & $\quad$ Jumlah & $\mathbf{3 . 1 8 6}$ & $\mathbf{3 . 1 5 5}$ & $\mathbf{3 . 6 9 0}$ & $\mathbf{3 . 4 3 8}$ \\
\hline & & 0.031 & 0.252 \\
\hline
\end{tabular}

Berdasarkan tabel 1, maka dapat ditentukan posisi organsiasi prodi PTM sebagaimana

Gambar 1. Berdasarkan Gambar 1 terlihat bahwa organisasi ini berada pada kuadran I (positif, positif), hal ini menandakan bahwaorganisasi dalam kondisi kuat dan berpeluang, Rekomendasi strategi yang diberikan adalah Progresif, artinya organisasi dalam kondisi prima dan mantap sehingga sangat dimungkinkan untuk terus melakukan ekspansi, memperbesar pertumbuhan dan meraih peluang secara maksimal demi kemajuan yang berkelanjutan.

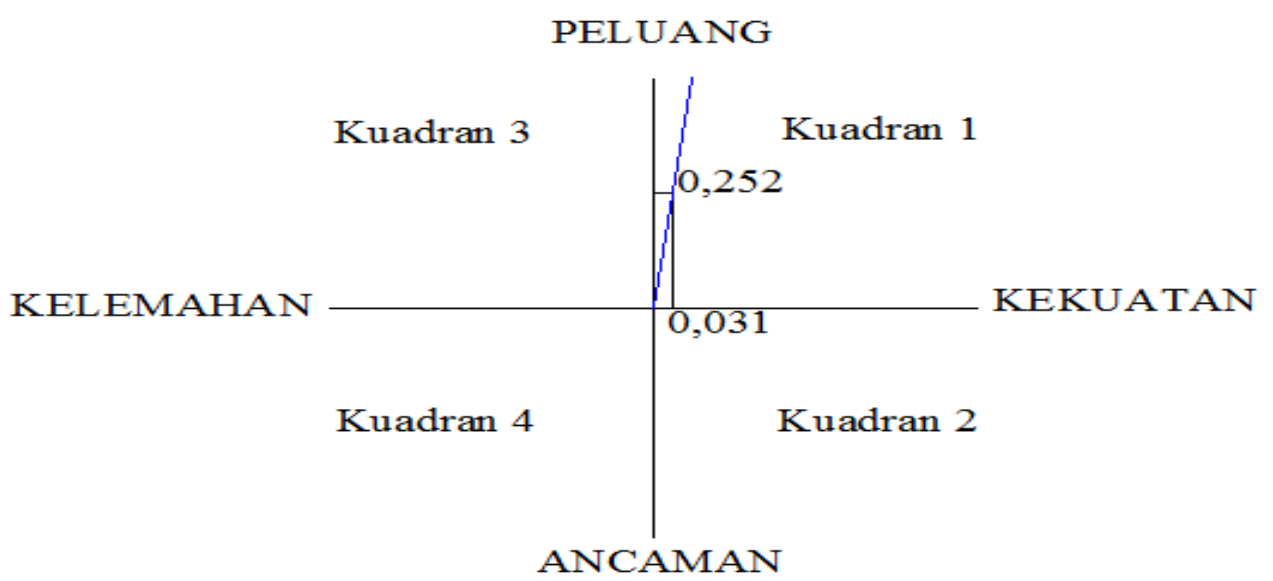

Gambar 1. Posisi organisasi Prodi PTM 
Deskripsi mengenai posisi organisasi di atas, yang memperlihatkan bahwa organisasi dalam keadaan kuat dan berpeluang adalah kalimat manis yang mungkin menyenangkan. Ingat bahwa secara matematis, angkanya berbeda sudutnya berbeda meskipun pada kuadran yang sama, penerjemahannya ke dalam bahasa strategi juga berbeda. Selain itu, Tim harus ingat, bahwa pernyataan tersebut masih bersifat general (kuantitatif), dan akan bermakna bila ditindaklanjuti dengan mendeskripsikan generalisasi tersebut ke dalam partisi-partisi (kualitatif). Dekripsi secara kualitatif inilah yang akan berguna bagi Tim untuk mengembangkan strategi tiap variabelnya.

Peluang

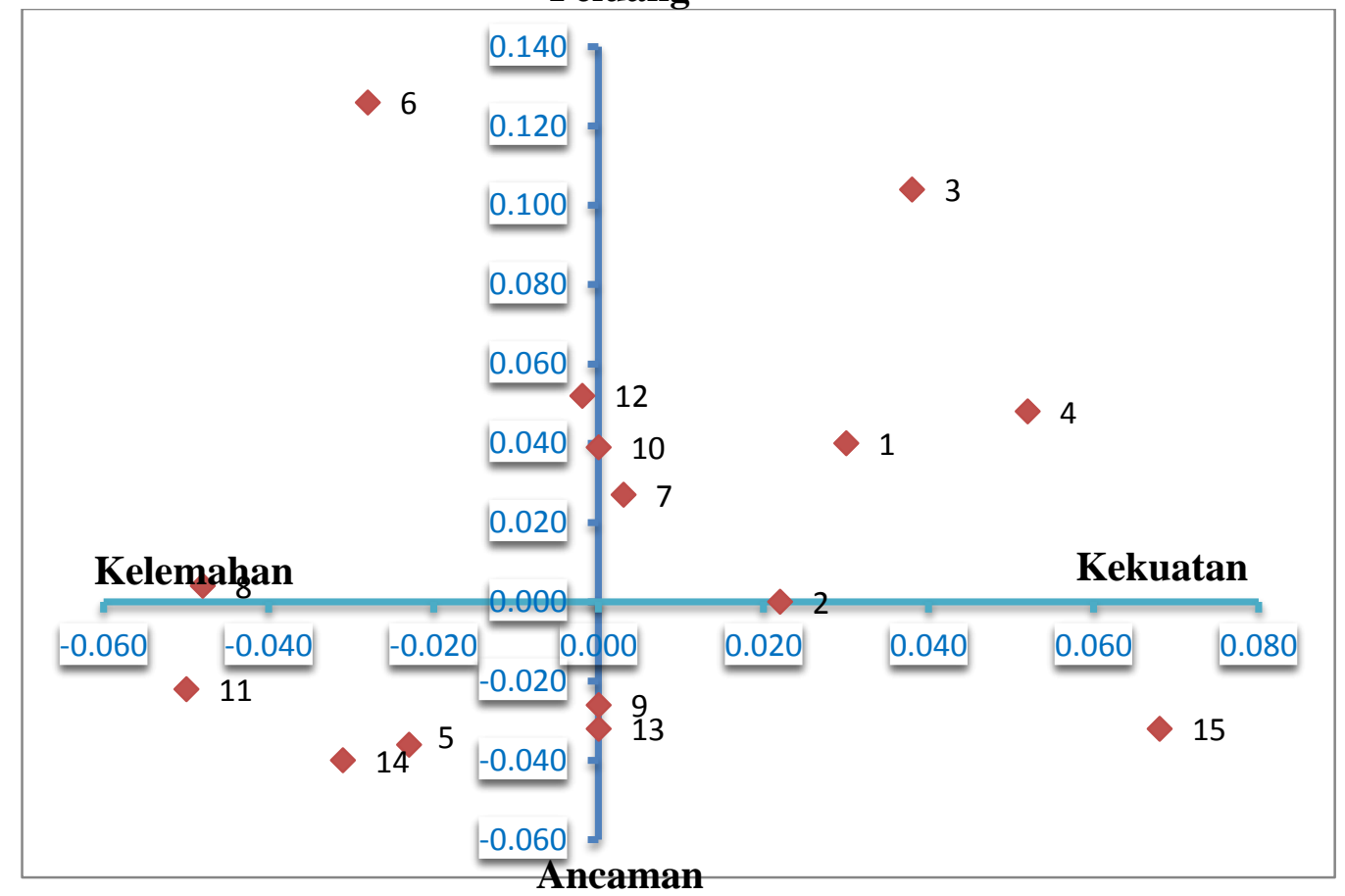

Gambar 2. Posisi organisasi masing-masing variabel dari Prodi PTM

Gambar 1 di atas menampilkan posisi lembaga secara kuantitatif (general), sedangkan gambar 2 menunjukkan posisi masing-,masing variabel. Berdasarkan gambar 2, tim dapat menterjemahkan makna tiap titiknya. Sebagai contoh, titik 1 (visi dan misi) berada pada kuadran 1 maknanya adalah visi dan misi organisasi dalam keadaan mantap dan berpeluang untuk digunakan sebagai dasar yang menuntun arah pencapaian tujuan. Titik 15 (P2M), berada pada kuadran 3. Pada titik 15 mengandung makna bahwa sebenarnya prodi memilki kekuatan SDM yang besar, namun ada banyak faktor yang menghambat sehingga P2M tidak berjalan. Rekomendasinya adalah program studi perlu mengubah strategi untuk memaksimalkan kekuatan yang dimiliki guna menghindari ancaman yang terkait dengan P2M. Dengan pola yang sama, tim dapat mengembangkan startegi menggunakan mastrik SWOT kualitatif untuk masingmasing variabel dengan melihat letak titik untuk masing-masing variabel.

Sampai dengan langkah ini berarti tim renstra telah selesai melakukan analisis lingkungan internal dan eksternal. Selanjutnya berdasarkan temuan yang diperoleh dari analisis SWOT kuantitatif, tim dapat meneruskan ke langkah berikutya untuk menemukan isu-isu 
strategis, pengembangan strategi, dan menemukan alternatif-alternatif strategi menggunakan analisis SWOT kualitatif.

\section{Isu-isu, Pengembangan, dan Alternatif-alternatif Strategi}

Bagian ini menjawab tiga pekerjaan sekaligus, yaitu menemukan isu-isu strategis, mengembangkan strategi, dan menemukan alternatif-alternatif strategi untuk mengatasi isu strategis yang ada. Ketiga pekerjaan tersebut dapat diselesaikan dengan menggunakan analisis SWOT kualitatif. Pada langkah ini, tim harus melakukan pentabelan untuk masing-masing variabel. Dengan mengacu analisis SWOT kuantitatif, berikut disajikan hasil simulasinya:

Tabel 2. Analisis SWOT kualitatif untuk mengembangkan strategi

\begin{tabular}{|c|c|c|}
\hline & OPPORTUNITIES & THREATS \\
\hline EKSTERNAL & $\begin{array}{l}\text { A. Kebijakan pemerintah } \\
\text { memperbanyak sekolah } \\
\text { kejuruan } \\
\text { B. Perhatian dunia usaha ke } \\
\text { sekolah semakin tinggi } \\
\text { C. Tren positif sekolah kejuruan } \\
\text { mendukung pencapaian visi }\end{array}$ & $\begin{array}{l}\text { A. Semakin banyak PTM lain } \\
\text { yang merumuskan visi, } \\
\text { misi dengan baik } \\
\text { B. Visi misi mudah dilupakan } \\
\text { oleh warga kampus }\end{array}$ \\
\hline STRENGTHS & BSC-SO & BSC-ST \\
\hline $\begin{array}{l}\text { 1. Kejelasan visi, misi dan } \\
\text { tujuan di prodi PTM } \\
\text { 2. Rumusan visi dan misi prodi } \\
\text { PTM sudah disosialisasikan } \\
\text { dengan baik } \\
\text { 3. Visi dan misi sesuai dengan } \\
\text { kebutuhan dunia kerja saat } \\
\text { ini }\end{array}$ & $\begin{aligned}> & \text { Penguatan kapasitas SDM } \\
& (1,2+\mathrm{A}, \mathrm{B}, \mathrm{C}) \\
& \text { Membangun hubungan yang } \\
& \text { lebih berkualitas dengan } \\
& \text { lembaga mitra }(1,3+\mathrm{B}, \mathrm{C})\end{aligned}$ & $\begin{array}{l}\text { Internalisasi } \\
\text { misi }(1,2+A C)\end{array}$ \\
\hline WEAKNESS & BSC-WO & BSC-WT \\
\hline $\begin{array}{l}\text { 1. Visi, misi belum sepenuhnya } \\
\text { dijadikan sebagai panduan } \\
\text { untuk penyusunan program } \\
\text { 2. Visi dan misi belum } \\
\text { sepenuhnya dipahami oleh } \\
\text { sivitas akademika }\end{array}$ & $\begin{aligned} & \text { Mengadakan evaluasi tentang } \\
& \text { pencapaian visi misi prodi } \\
&(2+\mathrm{B})\end{aligned}$ & $\begin{array}{l}\text { Meningkatkan penelitian } \\
\text { berbasis evaluasi prodi utk } \\
\text { mengetahui ketercapaian } \\
\text { visi dan misi prodi PTM } \\
(1,2+\text { AC) }\end{array}$ \\
\hline
\end{tabular}

Apabila 15 variabel telah dianalisis dengan teknik SWOT kuanitatif dan kualitatif sebagaimana tabel 2 , langkah selanjutnya adalah tim mengkaji sekali lagi dan akan menemukan bahwa masih terdapat beberapa pilihan strategi yang mungkin akan diputuskan. Beberapa pilihan strategi inilah yang akhirnya disebut sebagai alternatif-alternatif strategi. Alternatif strategi ini harus dipilih dan diputuskan sebagai pilihan strategi. Pilihan strategi yang telah diputuskan oleh tim kemudian direkap dan menjadi dokumen pengembangan strategi lembaga. Sampai dengan langkah ini tim telah memiliki daftra renstra namun belum didapatkan strategi prioritasnya. 
Tabel 2. Daftar pilihan Strategi Program Studi Pendidikan Teknik Mesin

\begin{tabular}{|c|c|c|}
\hline No & Rumusan Strategi & Variabel \\
\hline 1 & Penguatan kapasitas SDM untuk pencapaian visi, misi & Visi, misi \\
\hline 2 & $\begin{array}{l}\text { Membangun hubungan yang lebih berkualitas dengan } \\
\text { lembaga mitra }\end{array}$ & $\begin{array}{l}\text { Visi, Misi-Kerjasama-Peran } \\
\text { Dunia Usaha dan Industri } \\
\text { (DuDi) }\end{array}$ \\
\hline 3 & Peningkatan kualitas input mahasiswa (2/PS) & \\
\hline 4 & $\begin{array}{l}\text { Peningkatan Research Based Learning (RBL) dan } \\
\text { work based learning (WBL) }\end{array}$ & $\begin{array}{l}\text { Mahasiswa - Penelitian \& } \\
\text { Pengabdian }\end{array}$ \\
\hline 5 & Penguatan mata kuliah pilihan & Kurikulum \\
\hline 6 & Pemberdayaan dosen dalam Tridharma PT & Dosen \\
\hline 7 & $\begin{array}{l}\text { Penyelenggaraan laboratorium virtual, khususnya } \\
\text { CNC }\end{array}$ & Sarana Prasarana \\
\hline 8 & Penyelenggaraan pelatihan-pelatihan vocational & Keuangan \\
\hline 9 & Peningkatan efektifitas PI & Proses Pembelajaran \\
\hline 10 & Peningkatan efektivitas evaluasi pembelajaran & Proses Pembelajaran \\
\hline 11 & Pengembangan Customer Relationship Managemen & Manajemen \\
\hline 12 & Peningkatan kompetensi soft skill mahasiswa & $\begin{array}{l}\text { Peran Dunia Usaha dan } \\
\text { Industri (DuDi) }\end{array}$ \\
\hline 13 & $\begin{array}{l}\text { Menyelenggarakan kuliah pakar (praktisi) untuk mata } \\
\text { kuliah produktif }\end{array}$ & $\begin{array}{l}\text { Peran Dunia Usaha dan } \\
\text { Industri (DuDi) }\end{array}$ \\
\hline 14 & Peningkatan layanan dengan sistem IT & $\begin{array}{l}\text { Teknologi Informasi dan } \\
\text { Komunikasi }\end{array}$ \\
\hline 15 & $\begin{array}{l}\text { Menyelenggarakan Seminar-seminar ilmiah - regional, } \\
\text { nasional, dan internasional }\end{array}$ & Kerjasama - P2M \\
\hline 16 & $\begin{array}{l}\text { Pendirian program studi baru sesuai arah kebijakan } \\
\text { pemerintah }\end{array}$ & Peran Pemerintah \\
\hline 17 & Peningkatan peraihan dana hibah, khususnya P2M & Penelitian \& Pengabdian \\
\hline
\end{tabular}

\section{KESIMPULAN}

LPTK termasuk organisasi yang memiliki sumber daya tak terbatas. Peran LPTK di Indonesia sangat strategis dalam menopang pertumbuhan ekonomi dan kemajuan daya saing bangsa. Oleh karena itu LPTK harus bekerja keras untuk mampu merumuskan strategi yang efektif guna mewujudkan harapan bangsa Indonesia. Perencanaan strategis untuk LPTK perlu disusun sedemikian rupa sehingga kemajuan LPTK dan perannya dalam meningkatkan mutu dan relevansi di bidang pendidikan dapat dimonitor dan dievaluasi dengan terukur. Untuk dapat merumuskan strategi dalam perencanaan strategi diperlukan analisis lingkungan secara cermat 
agar diperoleh rumusan strategi yang efektif. Integrasi SWOT kuantitatif dan kualitatif terbukti efektif dalam memformulasi strategi untuk Pendidikan Teknologi dan Kejuruan.

\section{DAFTAR PUSTAKA}

Abraham , S.,C. (2006). Strategic Planning: A Practical Guide for Competitive success. London: Thomson South-Western.

Allio, R. (1988). The practical srategiest: Business and corporate strategy for the 1990. Social Science-Elsevier, 21, 104-1011.

Bryson, J.M. \& Einsweiler, R.C. (1988). Strategic Planning: Threats and Opportunities for Planners. Chicago: Planners Press / APA.

Bryson, J., M. (1999). Perencanaan strategis bagi organisasi nirlaba. Yogyakarta: Pustaka Pelajar.

Depdiknas. (2010). Sistem Penjaminan Mutu Perguruan Tinggi. Jakarta: Dikti.

Eko Indrajit, R., \& Djokopranoto, R. (2005). Manajemen Strategis Perguruan Tinggi. Jakarta: Universitas Atmajaya.

Hitt, M.A., et al. (2005). Strategic management: Competitivness and globalizations, concepts, and cases $\left(6^{\text {th }}\right.$ ed.). London: Thomson South-Western.

Oster, S., M. (1999). Modern competitive analysis ( $3^{\text {rd }}$ ed.). New York: Oxford University Press.

Rangkuti, F. (1997). Analisis SWOT: Teknik membedah kasus bisnis. Jakarta: Gramedia.

Rauch, P. (2007). SWOT analysis and SWOT strategy formulation for forest owner cooperations in Austria. Eur. J. Forest Res., 30, 413-420.

Warzynski, C. (2001). How can the balanced scorecard improve performance at your institution?. Pennsylvania: Pennsylvania State University.

Wheelen, T.L. \& Hunger, J.D. (1996). Strategic management $\left(5^{\text {th }}\right.$ ed.). Boston: Addison Wesley Publishing Company.

Wijaya, T. (2011). Manajemen kualitas jasa: Desain servqual, Qfd, dan Kano disertai contoh aplikasi dalam kasus penelitian. Jakarta: Indeks.

Wikipedia. (2008). Vocational education and training. Diambil pada tanggal 3 Agustus 2011, dari http://en.wikipedia.org/wiki/Vocational_Education_and_Training

Zohrabi, A. \& Manteghi, N. (2011). A proposed model for strategic planning in educational organizations. Social Science-Elsevier,76, 205- 210. 
